\title{
Analysis of decision support system on situational leadership styles on work motivation and em-
} ployee performance

\author{
Eni Wuryani ${ }^{a^{*}}$, Achmad Fathoni Rodli ${ }^{b}$, Sri Sutarsi ${ }^{b}$, Nuning Nurna Dewi ${ }^{b}$ and Donny Arif ${ }^{b}$
}

${ }^{a}$ Universitas Negeri Surabaya, Indonesia

${ }^{b}$ Universitas Maarif Hasyim Latif, Indonesia

\section{H R O N I C L E \\ A B S T R A C T}

Article history:
Received: June 20, 2020
Received in revised format:
August 302020
Accepted: September 18, 2020
Available online:
September 23, 2020
Keywords:
Decision support system
Situational leadership
Motivation
Employee Performance

Article history:

Received: June 20,2020

August 302020

Accepted: September 18,2020

Decision support system

Motivation

Employee Performance

\begin{abstract}
This study aims to obtain the results of employee performance appraisal through a decision support system (DSS) on situational leadership with work motivation as a connecting variable to employee performance. The use of this type of quantitative research with the number of respondents with a saturated sample technique will make this research more relevant and objective in showing the results. Data analysis using smart PLS 3.0 which resulted in the finding that the decision support system (DSS) in situational leadership had not been able to contribute to improve employee performance. It can be concluded that the role of technology in semi structured decision making must be based on sufficient data to help improve employee motivation and performance. In fact, leadership is still used to make unstructured decisions without paying attention to the data stored in the performance system. Performance indicators are not well-paid attention so that the value generated from this study shows negative results.
\end{abstract}

\section{Introduction}

Human resources are considered as important assets of an organization that are required to be competent according to their fields and has good performance in the workplace. While the human resources sector is one of the priorities in new trends and underwent major changes in terms of their repositioning and new roles in companies, Human Resource Management (HRM) has become a strategic plan in the organization (Jatobá et al., 2019). The performance of human resources must be considered since it can affect the progress of the organization and the objectives to be achieved. In the last period, most of the articles on human resource management (HRM) and employee performance focus on human resources in the department of a company, the selection of professional members can improve organizational performance (Gürbüz \& Albayrak, 2014). To get good performance, it takes high morale. Employees who have high morale will be happy and give full attention to their work. Often the human resources department claims to improve business performance and results but management asks for evidence from them, and often before the goal occurs they make a decision (McLean, 2006). It takes leaders with high motivation and has good decisions so that employees have good performance so that the goals of the organization/company can be achieved. Motivation can utilize a person using all his energy and mind to complete the work. Motivation can be broadly defined as the conceptuality of work motivation, motivation to work, and motivation to work beyond retirement limits (Pak et al., 2019). Highly motivated employees will work with full initiative, responsibility and discipline as well as being effective in doing work. With work performance all work will be completed with satisfying results and as expected. Employee work performance is also influenced by the leadership style adopted by the leadership. Leaders with good leadership style will have a great influence on the subordinates they lead so that the company's main goals can be realized. Conversely, if the leader has a bad leadership style it will make employees unable to carry out their duties and have poor performance. In their understanding,

* Corresponding author.

E-mail address: eniwuryani@unesa.ac.id (E. Wuryani) 
leadership theory considers that the impact of effective leadership in organizations can make the level of commitment to performance, they recognize that the factor of effective leadership can lead to high motivation for employees (Ufua et al., 2020). So, leaders must change leadership styles that are acceptable and provide comfort for their employees so that employees have good motivation and good performance. A leader must be able to provide full support for motivation and good performance, including in making decisions in the operations of the company/organization, so we need a system that can help leaders in making decisions properly called the Decision Support System (DSS). The system mentioned only analyzes organizational, technical and managerial aspects and the like, but other aspects contained in the human element as an organizational asset do not get any attention at all (Gudauskas et al., 2015). Studies of groups not supported by DSS have found that large groups of employees with leaders are less likely to split into factions or subgroups and leaders are useful in achieving task-oriented goals because leadership seems to have an impact on results (Rees \& Koehler, 2000). This research was conducted in a nonprofit organization in the form of the National Zakat Institute which manages ZISWAF (Zakat, Infaq, Shodaqoh, and Waqf) funds, social funds, and CSR (Corporate Social Responsibility).

\subsection{Theory and Hypothesis}

\subsubsection{DSS on Situational Leadership}

The decision support system (DSS) has been developed based on the information management system (Yun \& Ma, 2020). There is no definite understanding of the Decision Support System (DSS), the aim is to provide decision support through employee performance and systems (Gil et al., 2020). A lot of research on leadership theory in general really supports performance well, but if seen from the viewpoint of situational leadership theory, there are still some things that need to be improved and revised from this leadership theory. Although this system is the most widely known theory in the situational leadership domain, it is still one model that has not been proven by research (Thompson \& Vecchio, 2009). Therefore, several theories state the need for system support that is integrated with management in order to make good decision patterns in situational leadership theory. In addition, several studies on DSS prove that it not only affects group leadership but also affects leadership styles with the help of DSS (Kahai \& Avolio, 2013). However, the situational leadership style and conformity with what has been agreed upon will leave a profound history of the effectiveness of the DSS group (Rees \& Koehler, 2000). The most important thing in the context of the DSS examination process is that there are several models that can be used for scientific literacy, some of these models are in descriptive form, including in the contingency model (Bose \& Paradice, 1999). According to (Thompson \& Vecchio, 2009) statement of the invincible dimension of situational leadership is as follows:

1. Telling (instructional style leader) with indicators as following: Describe the roles of each, effective two-way communication, make a decision, additional instructions to clarify.

2. Selling (consulting style leader) with indicators as following: Decisions and opportunities for clarification, follower level of followers, encouragement to improve the performance of subordinates.

3. Participation (leader style) with indicators as follows: Active listener, support subordinates in taking risks, give praise to subordinates' task reports, build self-confidence.

4. Delegating (leader delegation style) with indicators as following: General description of the task, monitor the activities of subordinates, encourage the achievement of goals.

\subsubsection{Motivation}

Motivation guides behavior e it helps to determine what individuals do, and how they do it (Meyer et al., 2004). To date, little is known about why some line management developed certain types of leadership and not others, and there have been several attempts to explain the dominance of leadership motivation (Kanat-Maymon et al., 2020). For instance, (Chan \& Drasgow, 2001) explains about effective leadership by looking at the individual's point of view in the motivation to lead. However, the explanation of the will to lead is how one person chooses to lead in a different way than others. Work motivation is said to be linked to the delivery of quality of service by enhancing workers' performance as well as directing them towards personal and cooperation goals (Al-hassan et al., n.d.). There are two major types of motivation, i.e., intrinsic motivation (IM) and extrinsic motivation (EM) (Chai et al., 2017). Work motivation indicators used by researchers is Abraham Maslow's hierarchy of needs theory. This theory is also expressed in the research (Mawere et al., 2016). The theory expressed is:

1. Physical Needs. Is a basic need of humans who can in the form of food, drink, rest, biological needs and others, etc.

2. Safety and Security Needs. After physical needs, then next is the need such as security, health insurance, security assurance work, and retirement benefits.

3. Social Needs. Social needs are needs A and accepted by the social environment. An example of a working group compact, a good relationship between individuals and friendship.

4. Esteem Needs. This need is in the form of rewards for employees who excel in the form of recognition of their abilities and expertise.

5. Self-Actualization Needs. It is a need that resides in the individual placement in environment and self-development which can be there is a development / clear career path, present it promotion or promotion for employees who excel or involve employees in various activities that have challenges. 
From the description above, it can be seen that a person's work motivation consists of 5 (five) needs. Work motivation can affect the success of performance in an organization/company. Therefore, it is assumed that the DSS on situational leadership can improve work motivation by measuring it by the indicators that have been described. We, therefore, propose the following research hypothesis:

H-1. DSS on situational leadership has a positive relationship with work motivation.

\subsubsection{Employee Performance}

Today, anxiety and mental stress are the most common problems affecting individual circumstances and behavior. It is believed that good leadership is necessary to influence individual performance and productivity (Kour et al., 2019). The 21st Century workplace heavily depends on advancement on technology, hence putting pressure on both the employees and the organization in terms of performance and productivity (Chan \& Drasgow, 2001). The job performance scale developed by (Williams \& Anderson, 1991) is composed of an in-role behavior and an organizational citizenship behavior subscale, and is evaluated by supervisors; however, self-assessment has also been adopted in later studies (Zhang \& Liu, 2020). The approach taken to measure employee performance is a three-component model (Allen \& Meyer, 1990).

1. Affective Commitment (AC): Affective Commitment is the level of emotional attachment and how the employee's involvement is shown in working optimally. This aspect focuses on the psychological approach of employees with the company; their organization wants to continue working in the company (Meyer et al., 2004).

2. Continuance Commitment (CC): Continuance Commitment is when employees realize that costs are being used to leave the organization. This cost is viewed from the loss of benefits or loss of a strategic position as well as the rewards achieved in connection with that position (Meyer et al., 2004).

3. Normative Commitment (NC): Normative Commitment is when employees have an obligation to remain committed to the company. This obligation is due to a sense of indebtedness because the company has invested time and money in its obligations and continues to support other employees in their obligations in the company (Meyer et al., 2004).

By considering various indicators of the theory it is formulated that:

H-2 Work motivation has a positive relationship with employee performance.

H-3 DSS on situational leadership has a positive relationship with employee performance.

\section{Method}

This study uses a quantitative approach to get a clear picture of the results achieved. Quantitative methods are especially important to explore the extent and variation of change (within and across units) induced by the implementation strategies (Smith \& Hasan, 2020). With a quantitative approach, this study uses a population and a sample, collecting certain data with the aim of testing the predetermined hypothesis (ARIF et al., 2020). This type of research uses a questionnaire with a Likert scale in the form of a checklist. Likert method for measuring attitudes by combining the scores of each question. This method is called the sum ranking (Salkind, 2012). Each question has a five-scale response: least, less, moderate, more, and most with the scores for the scale being 1,2,3,4, and 5, respectively (Vonglao, 2017). The scale used in measuring the variable indicator with a total of 70 respondents with weighted values are:

Table 1

Score Likert

\begin{tabular}{ccc}
\hline Code & Information & Score \\
\hline SA & Strongly Agree & 5 \\
A & Agree & 4 \\
SIA & Simply Agree & 3 \\
DA & Disagree & 2 \\
SDA & Strongly Disagree & 1 \\
\hline
\end{tabular}

The index in the form of a percentage is calculated by:

Index $(\%)=($ Total Score $/$ Maximum Score $) \times 100$

After calculating the index in the form percentage, then the assessment interval can be seen as in under:

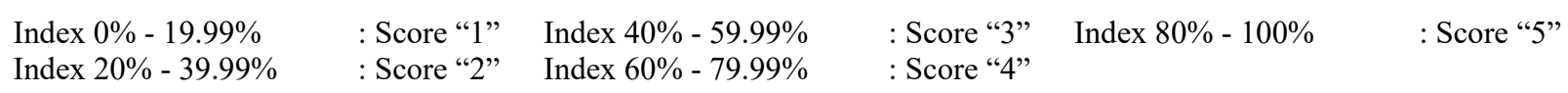

This study uses work motivation latent variables (variables that cannot be measured directly and must use several indicators or questionnaire statements), has a hierarchical hypothesis simultaneously, and is exploratory or extended to theory so that 
the data is analyzed using the path analysis method or path analysis. Path analysis describes the important flows associated with paper citations. it is a technique that can explain academic relationships, behind the scenes, and broader lines of science by visualizing the use of citations between institutions (Jung \& Lee, 2020). Path analysis in this study was carried out using smartPLS 3.0. Partial least squares (PLS) regression is a widely used method in the chemometrics community that can handle the high dimensional and high correlated spectroscopy datasets (Wold et al., 2001). The original form of PLS regression extracts some latent variables obtained from all variables, which cannot choose which one is more important (Li et al., 2019). Much literature about the variable selection in PLS have appeared over the last two decades. Generally, these methods can be categorized into three types: filter, wrapper, and embedded methods (Mehmood et al., 2012).

The steps in the analysis using PLS are as follows:

1. Designing a Measurement Model (Outer Model)

Measurement model to determine the validity and reliability relates the indicator to its measured latent variable in 3 (three) ways, namely:

1.1 Convergent Validity

Measuring the magnitude of the correlation between the constructs and the latent variables which can be seen from the standardized loading factor. The standardized loading factor describes the magnitude of the correlation between each measurement item (indicator) and its construct which is said to be valid if it has a value $>0.5$.

1.2 Discriminant Validity

Comparing the discriminant validity and the square root of the average variance extracted (AVE) assessed based on the crossloading measurement with the construct. If the value is higher than the correlation value between constructs, a good discriminant validity will be achieved. The AVE calculation formula is:

$\mathrm{AVE}=\frac{\Sigma \lambda i^{2}}{\Sigma \lambda i^{2}+\Sigma 1 \operatorname{var}(\varepsilon i)}$

1.3 Composite Reliability

If the value of composite reliability $>0.8$, it can be said that the construct has high or reliable reliability and $>0.6$ is said to be quite reliable.

2. Designing the Structural Model (Inner Model)

The evaluation was carried out using the R-square (R2) for the dependent construct, the Stone-Geisser Q-square test for the relevant predictive and t-test as well as the significance of the structural path parameter coefficient. R2 can be used to assess substantive effects between the independent latent variables and the dependent latent variables.

3. Hypothesis Testing (Resampling Bootstrapping)

The design of hypothesis testing in this study is presented based on research purposes. The confidence level used is $95 \%$ so that the inaccuracy limit is $(\alpha)=5 \%=0.05$ and produces t-table value of 1.96 .

The conceptual model in Fig. 1 shows the outline of the research flow carried out.

$\mathrm{H}_{3}$

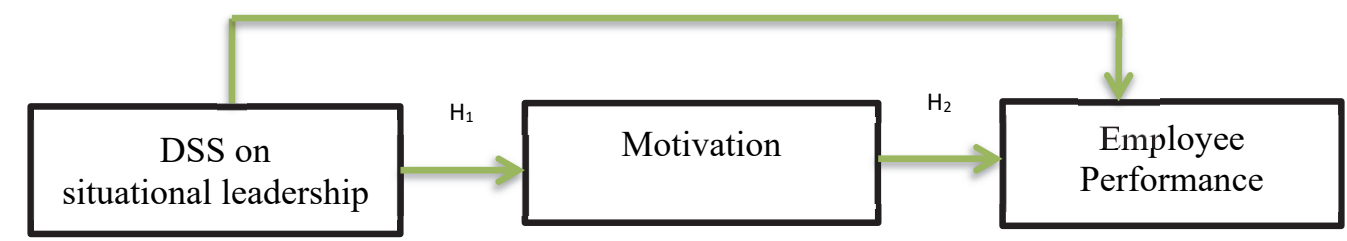

Fig. 1. Theoretical model showing hypothesized relationships among the DSS on situational leadership, motivation and employee performance

\section{Result}

\subsection{Respondent Characteristics}

The census sample was taken by all employees totaling 70 respondents, which are interrelated between top management and line management. To see respondents' responses to the DSS indicators on situational leadership styles on work motivation and employee performance are:

Table 2

Index Score Variable

\begin{tabular}{|c|c|c|c|c|c|c|c|}
\hline \multirow{2}{*}{ Variable } & \multicolumn{5}{|c|}{ Average Score } & \multirow{2}{*}{$\begin{array}{c}\text { Total Average } \\
\text { Score }\end{array}$} & \multirow{2}{*}{ Index } \\
\hline & SA & A & SIA & DA & SDA & & \\
\hline DSS on Situational Leadership (X) & 107.92 & 140 & 31.25 & 6 & 0 & 285.17 & $81.48 \%$ \\
\hline Motivation $(Z)$ & 110.67 & 141.6 & 32.2 & 3.4 & 0 & 287.8 & $82.23 \%$ \\
\hline Employee Performance (Y) & 114.67 & 154.13 & 22.2 & 1.93 & 0.06 & 293 & $83.71 \%$ \\
\hline
\end{tabular}


To determine the percentage value of the Likert scale answers, it is determined from the number of answers that have been filled in by the respondent. Table 2 data shows that the number of respondents for the DSS variable on situational leadership is $81.48 \%$, indicating that the role of the DSS is crucial in determining decisions taken by leaders to support employee performance. Motivation also has a percentage value of $82.23 \%$, indicating that many respondents agree with the criteria proposed by researchers regarding the close relationship between DSS on situational leadership and motivation in determining employee performance improvement. Research (Kanat-Maymon et al., 2020) also reveals the same thing that certain types of motivation associated with certain leadership styles will be related to the work motivation of their subordinates.

\subsection{Measurement Model (Outer Model)}

In analyzing the measurement model, the PLS model is evaluated by evaluating the outer and inner models. Before measuring the outer model, an image of the algorithm results will first be presented:

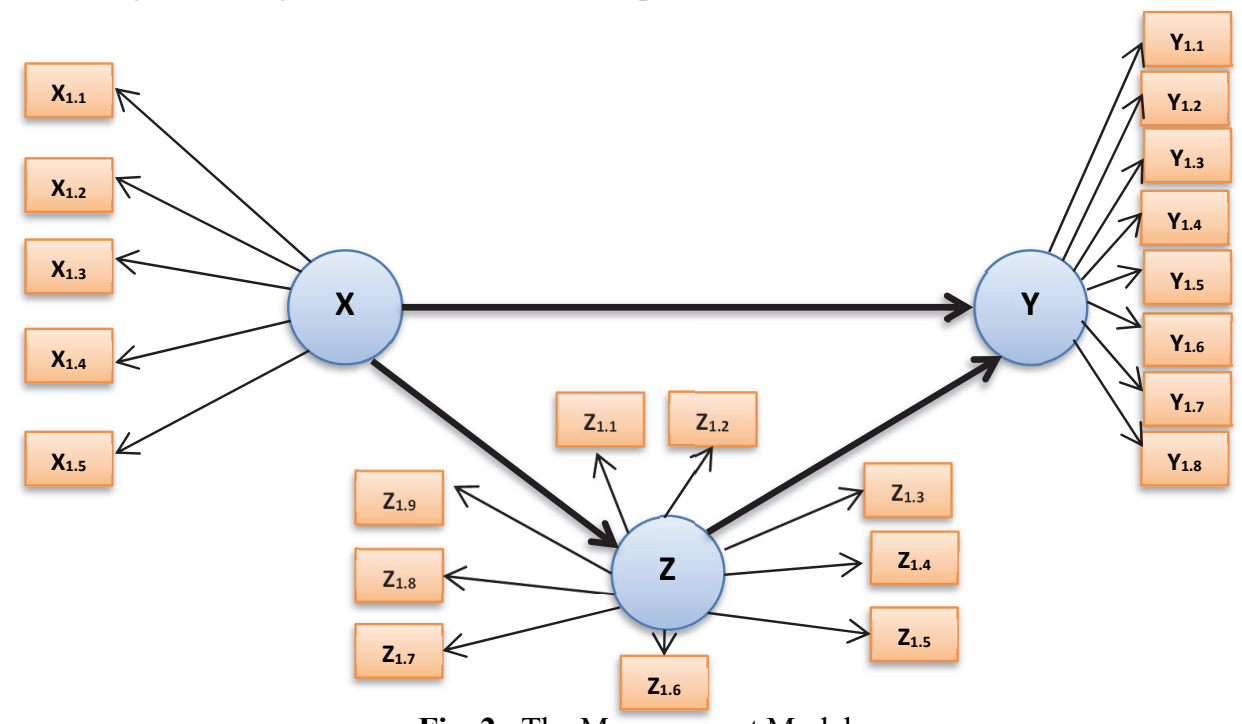

Fig. 2. The Measurement Model

Fig. 2 shows that there are several indicators that have values to measure constructs. The use of loading factors according to the image is to test the convergent validity of each variable, so the higher the loading factor value, the better. PLS model evaluation is done by evaluating the outer model and inner model. Table 3 shows the outer loadings for the DSS variable on situational leadership measured by 5 indicators $\left(X_{1.1}-X_{1.5}\right)$, with a loading value range of $0.705-0.813$. Because the five research indicators have a loading range of more than 0.50 and the $t$ count of each indicator is greater than 1.96 , the five indicators have accuracy in forming the DSS variable on situational leadership. Table 4 shows the external loading for the DSS variable on situational leadership as measured by 9 indicators $\left(Z_{1.1}-Z_{1.9}\right)$, with a loading value range of $0.765-0.852$.

Table 3

Outer Loadings DSS on Situational Leadership (X)

\begin{tabular}{|c|c|c|c|c|}
\hline Variable & Sample Original (O) & Mean (M) & Standard Deviation (STDEV) & T-Statistic (O/STERR) \\
\hline $\mathrm{X}_{1.1}$ & 0.726 & 0.721 & 0.077 & 9.373 \\
\hline $\mathrm{X}_{1.2}$ & 0.813 & 0.807 & 0.043 & 19.094 \\
\hline $\mathrm{X}_{1.3}$ & 0.731 & 0.726 & 0.063 & 11.542 \\
\hline $\mathrm{X}_{1.4}$ & 0.801 & 0.793 & 0.055 & 14.469 \\
\hline $\mathrm{X}_{1.5}$ & 0.705 & 0.695 & 0.080 & 8.769 \\
\hline
\end{tabular}

Because the five research indicators have a loading range of more than 0.50 and the $t$ count of each indicator is greater than 1.96 , the five indicators have accuracy informing work motivation variables. The last variable is employee performance as measured by 8 research indicators $\left(\mathrm{Y}_{1.1}-\mathrm{Y}_{1.8}\right)$. The eight indicators have a loading range of $0.727-0.876$ whose loading value is greater than 0.50 and the calculated $t$ value is greater than 1.96 . This means that the research indicators are correct/valid in forming employee performance variables. Based on the results of the convergent validity test, it can be concluded that all research indicators in testing the hypothesis have met the convergent validity requirements. This can be seen from the loading value for each indicator that has met the rule of thumb required for partial least square analysis. One way to compute convergent validity coefficients involves having an individual who is well acquainted with the target complete the same questionnaires in a peer rating format and then to correlate the peer responses with the target responses to items (Plouffe et al., 2017). Furthermore, the discrimination validity test is assessed from the cross-loading which aims to find out which constructs have adequate discrimination. The outer loadings table above shows the cross-loading value of the DSS on situational leadership, work motivation, and employee performance which has a higher loading value than other loading values. The results of measuring the validity of discrimination on the DSS on situational leadership, work motivation, and employee performance are declared valid. 
Table 4

Outer Loadings Motivation (Z)

\begin{tabular}{lcccc} 
Variable & $\begin{array}{c}\text { Sample } \\
\text { Original (O) }\end{array}$ & Mean (M) & Standard Deviation (STDEV) & T-Statistic (O/STERR) \\
\hline$Z_{1.1}$ & 0.771 & 0.765 & 0.069 & 11.182 \\
$Z_{1.2}$ & 0.849 & 0.845 & 0.044 & 19.458 \\
$Z_{1.3}$ & 0.766 & 0.766 & 0.062 & 12.274 \\
$Z_{1.4}$ & 0.832 & 0.829 & 0.049 & 17.109 \\
$Z_{1.5}$ & 0.852 & 0.849 & 0.048 & 17.700 \\
$Z_{1.6}$ & 0.765 & 0.756 & 0.057 & 12.027 \\
$Z_{1.7}$ & 0.785 & 0.777 & 0.049 & 13.684 \\
$Z_{1.8}$ & 0.768 & 0.765 & 0.058 & 15.783 \\
$Z_{1.9}$ & 0.782 & 0.775 & & 13.411 \\
\hline
\end{tabular}

Table 5

Outer Loadings Employee Performance (Y)

\begin{tabular}{|c|c|c|c|c|}
\hline Variable & Sample Original $(0)$ & Mean (M) & Standard Deviation (STDEV) & T-Statistic (O/STERR) \\
\hline$Y_{1.1}$ & 0.727 & 0.724 & 0.086 & 8.454 \\
\hline $\mathrm{Y}_{1.2}$ & 0.816 & 0.813 & 0.047 & 17.201 \\
\hline $\mathrm{y}_{1.3}$ & 0.820 & 0.818 & 0.041 & 20.165 \\
\hline$Y_{1.4}$ & 0.845 & 0.840 & 0.042 & 20.297 \\
\hline $\mathrm{Y}_{1.5}$ & 0.846 & 0.846 & 0.038 & 22.338 \\
\hline $\mathrm{Y}_{1.6}$ & 0.876 & 0.877 & 0.030 & 29.036 \\
\hline $\mathrm{Y}_{1.7}$ & 0.802 & 0.802 & 0.039 & 20.564 \\
\hline $\mathrm{Y}_{1.8}$ & 0.737 & 0.729 & 0.073 & 10.063 \\
\hline
\end{tabular}

Table 6

Composite Reliability and AVE

\begin{tabular}{lcc}
\multicolumn{1}{c}{ Variable } & Composite Reliability & AVE \\
\hline DSS on Situational Leadership (X) & 0.920 & 0.572 \\
Motivation (Z) & 0.938 & 0.636 \\
Employee Performance (Y) & 0.940 & 0.656 \\
\hline
\end{tabular}

To check convergent validity, each Average Variance Extracted (AVE) latent variable is evaluated. Again from table 6, it is found that all AVE values are greater than the acceptable threshold of 0.5 so that the convergent validity is confirmed (Wong, 2013). The AVE value of the DSS on situational leadership variable is 0,572 , work motivation variable is 0,636 and the last employee performance variable is 0,656 , This shows that the average value of these variables has a convergent value that meets the standard requirements. Whereas for composite reliability it is said to have high reliability or reliable if the composite reliability value is more than 0.8 and it is declared quite reliable if the composite reliability value is more than 0.6 (Wong, 2013). The composite reliability value of the situational leadership variable is 0.920 , the work motivation variable is 0.938 and the employee performance variable is 0.940 . All variables have a composite reliability value of more than 0.8 and it can be concluded that the construct has high reliability.

\subsection{Structural Model (Inner Model)}

The structural model was tested with the R Square value from the goodness fit model test (Xiaohui, 2016). To measure the level of validity of forming the independent variable on the dependent variable, namely $\mathrm{R}^{2}$. The prediction model of the research model used is said to be good if the $\mathrm{R}^{2}$ value is high based on the results of the R Square calculation processed with Smart PLS 3.0. Based on Table 7 above, the DSS on situational leadership (X) affects work motivation (Z) has an $R^{2}$ value of 0.622 or $62.2 \%$, which states that the model is "strong" or has a substantive influence on work motivation variables and employee performance and the rest $37.8 \%$ is influenced by other variables not included in this study. DSS on situational leadership (X) and work motivation (Z) affect employee performance (Y) has an $\mathrm{R}^{2}$ value of 0.616 or $61.6 \%$ which also means that the model is "strong" or has a substantive influence on employee performance variables.

Table 7

R Square Value

\begin{tabular}{lll}
\hline & Variable & Value R $^{2}$ \\
\hline Motivation (Z) & 0.622 \\
Employee Performance (Y) & 0.616 \\
\hline
\end{tabular}

\section{Path Coefficient Analysis}

In the structural model, the estimated coefficient value for the path relationship is obtained after bootstrapping which is processed with Smart PLS 3.0 (Xiaohui, 2016). The results of the path coefficient analysis show that DSS on social leadership has not made a positive contribution to employee performance with a t value of less than 1.96. whereas DSS on situational leadership has a very large impact on employee motivation with a $t$ value greater than 1.96. Conversely, the $t$ value for work motivation also has not made a positive contribution to employee performance in accordance with the table values that have been tested. 
Table 8

Path Coefficient

\begin{tabular}{|c|c|c|c|c|c|}
\hline Variable & $\begin{array}{c}\text { Sample } \\
\text { Original (O) }\end{array}$ & $\begin{array}{l}\text { Mean } \\
(\mathbf{M})\end{array}$ & $\begin{array}{c}\text { Standard Deviation } \\
\text { (STDEV) }\end{array}$ & $\begin{array}{c}\text { T-Statistic } \\
\text { (O/STERR) }\end{array}$ & Information \\
\hline DSS on situational Leadership $\rightarrow$ Motivation & 0,494 & 0,475 & 0,159 & 3114 & Significant \\
\hline Motivation $\rightarrow$ Employee Performance & 0,167 & 0,161 & 0,136 & 1,231 & Not significant \\
\hline DSS on situational Leadership $\rightarrow$ Employee Performance & 0,113 & 0,126 & 0,136 & 0,831 & Not significant \\
\hline
\end{tabular}

\section{Discussion}

Keen (1980) stated that the purpose of the DSS is to assist the leader in making decisions, solve semi structured problems, support assessments, and improve the effectiveness of decision making and not for efficiency. From the results of testing the hypothesis that the DSS on situational leadership has a positive and significant effect on motivation working with the original sample of 0.494 and a T-statistic value of 3.114 which indicates a value of $>1.96$. DSS on situational leadership can motivate work in various ways in order to achieve the organizational goals that have been set. Assistance from DSS can encourage leaders who are able to adapt to employee conditions to help employees have high work motivation so as to produce a good performance and contribute to achieving organizational goals. By measuring the indicators described in theory, effectiveness occurs in relation to work motivation. With the help of DSS, the leadership style will be more effective in building relevant closeness to subordinates. Leaders will find it easier to adjust to the conditions experienced by employees in completing all their work. From the research results, it is clear that the value of the positive relationship between DSS on situational leadership and work motivation is clear. Different results occurred in the DSS value on situational leadership with employee performance and work motivation with employee performance which did not show a positive relationship between variables. in leadership relationships that have been supported by the existence of a DSS, for example, attendance, digital recording of work results and digital work hours calculations can help leaders make decisions to reward outstanding employees, but this has not happened and decisions are still being made in an unstructured manner with managers as the main control of the decision system is not based on the percentage of performance shown by the system. The impact of unstructured decisions such as this makes work motivation also shows a negative number so that there is no significant effect on employee performance.

\section{Conclusion}

1. There is a positive and significant influence between DSS on situational leadership and work motivation with the original sample. Thus, leaders who apply situational leadership well will increase employee motivation. Employees who have high work motivation will continue to do better in completing the job responsibilities that have been given.

2. There is a positive and insignificant influence between leadership Situational and employee performance with the original sample so it can be concluded that $\mathrm{H}_{0}$ is accepted and $\mathrm{H}_{\mathrm{i}}$ is rejected. Thus, leaders who implement DSS on situational leadership have not improved employee performance. If the DSS on situational leadership is implemented poorly, it will reduce employee performance.

3. There is a positive and insignificant influence between work motivation and employee performance with the original sample so that it can be concluded that $\mathrm{H}_{0}$ is accepted and $\mathrm{H}_{\mathrm{i}}$ is rejected. Thus, high work motivation does not necessarily improve employee performance. Good employee performance will be achieved by carrying out work with discipline and responsibility.

\section{References}

Al-hassan, A., Papaioannou, M., Skancke, M., \& Sung, C. C. (n.d.). Sovereign Wealth Funds: Aspects of Governance Structures and Investment Management.

Allen, N. J., \& Meyer, J. P. (1990). The measurement and antecedents of affective, continuance and normative commitment to the organization. Journal of Occupational Psychology, 63(1), 1-18.

ARIF, D., YUCHA, N., SETIAWAN, S., OKTARINA, D., MARTAH, V., \& MUTTAQIIN, N. (2020). Applications of Goods Mutation Control Form in Accounting Information System: A Case Study in Sumber Indah Perkasa Manufacturing, Indonesia. The Journal of Asian Finance, Economics and Business, 7(8), 419-424.

Bose, U., \& Paradice, D. B. (1999). The effects of integrating cognitive feedback and multi-attribute utility-based multicriteria decision-making methods in GDSS. Group Decision and Negotiation, 8(2), 157-182.

Chai, S. C., Teoh, R. F., Razaob, N. A., \& Kadar, M. (2017). Work motivation among occupational therapy graduates in Malaysia. Hong Kong Journal of Occupational Therapy, 30, 42-48.

Chan, K. Y., \& Drasgow, F. (2001). Toward a theory of individual differences and leadership: understanding the motivation to lead. The Journal of Applied Psychology, 86(3), 481-498.

Gil, M., Wróbel, K., Montewka, J., \& Goerlandt, F. (2020). A bibliometric analysis and systematic review of shipboard decision support systems for accident prevention. Safety Science, 128 (March), 104717.

Gudauskas, R., Jokubauskiene, S., Zavadskas, E. K., Kaklauskas, A., Binkyte, A., Peciure, L., Budryte, L., \& Prialgauskas, 
D. (2015). Intelligent decision support system for leadership analysis. Procedia Engineering, 122(Orsdce), $172-180$.

Gürbüz, T., \& Albayrak, Y. E. (2014). An engineering approach to human resources performance evaluation: Hybrid MCDM application with interactions. Applied Soft Computing Journal, 21, 365-375.

Jatobá, M., Santos, J., Gutierriz, I., Moscon, D., Fernandes, P. O., \& Teixeira, J. P. (2019). Evolution of artificial intelligence research in human resources. Procedia Computer Science, 164, 137-142.

Jung, H., \& Lee, B. G. (2020). Research trends in text mining: Semantic network and main path analysis of selected Journals. Expert Systems With Applications, 113851.

Kahai, S. S., \& Avolio, B. J. (2013). Effects of leadership style and anonymity on the discussion of an ethical issue in an electronic meeting system context. Leadership at a Distance: Research in Technologically-Supported Work, 95-125.

Kanat-Maymon, Y., Elimelech, M., \& Roth, G. (2020). Work motivations as antecedents and outcomes of leadership: Integrating self-determination theory and the full range leadership theory. European Management Journal.

Keen, P. G. (1980). Adaptive design for decision support systems. Acm Sigoa Newsletter, 1(4-5), 15-25.

Kour, J., El-Den, J., \& Sriratanaviriyakul, N. (2019). The Role of Positive Psychology in Improving Employees' Performance and Organizational Productivity: An Experimental Study. Procedia Computer Science, 161, 226-232.

Li, C.-Q., Xiao, N., Wen, Y., He, S.-H., Xu, Y.-D., Lin, Y.-W., Li, H.-D., \& Xu, Q.-S. (2019). Collaboration patterns and network in chemometrics. Chemometrics and Intelligent Laboratory Systems, 191, 21-29.

Mawere, M., Mubaya, T., Reisen, M., \& van Stam, G. (2016). Maslow's Theory of Human Motivation and its Deep Roots in Individualism: Interrogating Maslow's Applicability in Africa.

McLean, M. (2006). Evaluating the importance and performance of the human resources function: An examination of a medium sized Scottish retailer. Journal of Retailing and Consumer Services, 13(2), 143-156.

Mehmood, T., Liland, K. H., Snipen, L., \& Sæbø, S. (2012). A review of variable selection methods in Partial Least Squares Regression. Chemometrics and Intelligent Laboratory Systems, 118, 62-69.

Meyer, J. P., Becker, T. E., Hautes, E., \& Vandenberghe, C. (2004). Employee commitment and motivation : A conceptual analysis and integrative model, 89(6), 991-1007.

Pak, K., Kooij, D. T. A. M., De Lange, A. H., \& Van Veldhoven, M. J. P. M. (2019). Human Resource Management and the ability, motivation and opportunity to continue working: A review of quantitative studies. Human Resource Management Review, 29(3), 336-352.

Plouffe, R. A., Paunonen, S. V., \& Saklofske, D. H. (2017). Item properties and the convergent validity of personality assessment: A peer rating study. Personality and Individual Differences, 111, 96-105.

Rees, J., \& Koehler, G. J. (2000). Leadership and group search in group decision support systems. Decision Support Systems, $30(1), 73-82$.

Salkind, N. J. (Ed.). (2010). Encyclopedia of research design (Vol. 1). Sage.

Smith, J. D., \& Hasan, M. (2020). Quantitative approaches for the evaluation of implementation research studies. Psychiatry Research, 283(March), 112521.

Thompson, G., \& Vecchio, R. P. (2009). Situational leadership theory: A test of three versions. Leadership Quarterly, 20(5), $837-848$

Ufua, D. E., Salau, O. P., Ikpefan, O., Dirisu, J. I., \& Okoh, E. E. (2020). Addressing operational complexities through reinventing leadership style: A systemic leadership intervention. Heliyon, 6(7), e04270.

Vonglao, P. (2017). Application of fuzzy logic to improve the Likert scale to measure latent variables. Kasetsart Journal of Social Sciences, 38(3), 337-344.

Williams, L. J., \& Anderson, S. E. (1991). Job satisfaction and organizational commitment as predictors of organizational citizenship and In-Role behaviors. Journal of Management, 17(3), 601-617.

Wold, S., Sjöström, M., \& Eriksson, L. (2001). PLS-regression: a basic tool of chemometrics. Chemometrics and Intelligent Laboratory Systems, 58(2), 109-130.

Wong, K. K. K.-K. (2013). 28/05 - Partial least squares structural equation modeling (PLS-SEM) techniques using SmartPLS. Marketing Bulletin, 24(1), 1-32.

Xiaohui, Y. (2016). Chapter 4 - Data Analysis 87. In Politeness and Audience Response in Chinese-English Subtitling.

Yun, Y., \& Ma, D. (2020). Human-computer interaction-based Decision Support System with Applications in Data Mining. Future Generation Computer Systems.

Zhang, C., \& Liu, L. (2020). The effect of job crafting to job performance. Knowledge Management Research and Practice, $00(00), 1-10$.

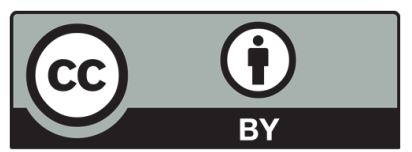

(C) 2020 by the authors; licensee Growing Science, Canada. This is an open access article distributed under the terms and conditions of the Creative Commons Attribution (CC-BY) license (http://creativecommons.org/licenses/by/4.0/). 